\title{
YIELD AND GRAIN QUALITY OF HULLESS SPRING BARLEY IN FIELD TRIALS UNDER DIFFERENT NITROGEN MANAGEMENT CONDITIONS
}

\author{
Māra Bleidere*, Sanita Zute*, Linda Brunava*, Natālija Bobere**, and Ida Jākobsone** \\ * State Stende Cereals Breeding Institute, Dižstende "Dižzemes", LV-3258, LATVIA; \\ maara.bleidere@stendeselekcija.Iv \\ ** University of Latvia, Faculty of Chemistry, Food Chemistry Centre, Kr. Valdemāra iela 48, Rīga, LV-1013, LATVIA; \\ ida.jakobsone@lu.lv
}

Communicated by Zinta Gaile

\begin{abstract}
The aim of the study was to evaluate the yield and grain quality (1000 kernel weight, test weight, crude protein, starch, $\beta$-glucans, total phenolic content, antiradical scavenging activity and $\alpha$-tocopherol content) variation of three hulless spring barley (Hordeum vulgare L.) genotypes under different levels of $N$, in relation to weather characteristics. The field experiments were carried out at the State Stende Cereal Breeding Institute. Three hulless barley genotypes 'Kornelija'; 'ST 1165'; ST 1185' were studied during two years (2011 and 2012) using three levels of nitrogen (N80; N80+40; N80+80) by split application at the end of the tillering stage. The effects of genotype, $N$ treatment and genotype by $N$ treatment interaction contribute the variation in yield and grain quality traits for hulless barley genotypes. There were considerable differences between crop years in response of hulless genotypes to top-dressing $N$, with significantly $(\mathrm{P}<0.05)$ higher grain yield, 1000 kernel weight, test weight, starch and $\beta$-glucans in the growing season of 2012, when rainfall was optimal at the tillering and stem-elongation growth stages. In 2012, a significant ( $\mathrm{P}<0.05)$ response to top-dressing $N$ was recorded for grain yield and $1000 \mathrm{kernel}$ weight (at rate N120), crude protein, starch and $\beta$-glucans (at rate N160). The maximum values of total phenolic content, antiradical scavenging activity (in 2011) and -tocopherol content (in 2012) were obtained with application of $160 \mathrm{~kg} \mathrm{~N} \mathrm{ha}{ }^{-1}$. Hulless line '1185' gave the highest grain yield, starch, $\alpha$-tocopherol content and radical scavenging activity, but variety 'Kornelija' formed significantly higher TKW, crude protein and $\beta$-glucans content.
\end{abstract}

Key words: hulless barley, yield, grain quality, $N$ fertilization.

\section{INTRODUCTION}

Barley (Hordeum vulgare L.) is an important contribution to food production and the economy in Europe. Hulless barley (HB) research and development is now receiving more emphasis with potential for various end uses also in Latvia. HB has been recognised as being more valuable and economic in the food industry than covered barley, because the interest of consumers in health and promoting food products is increasing (Newman and Newman, 2006). HB might be one of the ingredients in such products. Unlike covered barley, it is possible to use it in food products directly without de-husking. Thus, the food products include also the outer parts of grain, which contain valuable essential amino acids and vitamins. It has been suggested to include barley in food also due to its low glycemic index (Charalampopouos et al., 2002) and association with lower risk of cancer and heart disease (Ames et al., 2006; Ames and Rhymer, 2008).
Hulless barley kernels contain high levels of $\beta$-glucans, and much of the research on the health-promoting properties of barley has focused on mechanisms that involve $\beta$-glucans (Pins and Kaur, 2006). New barley cultivars have been generated specifically for food use, possessing increased beta-glucan, desirable starch composition profiles, and improved milling and processing traits (Ames, 2006). The quantity of $\beta$-glucans of barley grain is primarily associated with genotype and environmental factors (Leistrumaite and Paplauskiene, 2005). Nitrogen levels in soil and high $\mathrm{N}$ fertiliser amounts should significantly increase $\beta$-glucans content in barley (Guler, 2003). Comparison of covered and HB showed that the latter generally contains more protein, starch, and $\beta$-glucans (Newman and Newman, 2006).

Among cereals, barley could be a good source of tocopherols and tocotrienols, which are important phytochemical compounds with antioxidant activity and potential benefits for human health (Colombo, 2010). The cultivation method had an important effect on tocopherol concentrations in bar- 
ley (Tsochatzis et al., 2012). Chemical treatment and fertilisation statistically significantly increased the content of isomer $\alpha$-tocopherol (Ehrenbergerova et al., 2006).

Most phenolic compounds are bound to cell walls and mainly can be found in the bran and germ fractions, indicating that whole cereal flours also from HB provide greater overall physiological effects and higher health benefits (Dykes and Rooney, 2007). It has been confirmed that metabolites like phenolic compounds possess antiradical and antioxidant activity and play a preventive role in the development of cancer, heart and age-related diseases (Halliwell, 2007). Total phenolic content was shown to have strong correlation with antiradical scavenging activity in a study by H. Zhao et al. (2008) with spring barley.

Variety selection is and will become more important, as the various industries demand specific characteristics. Also in agriculture, besides grain quality, the adoption of varieties to the respective site of cultivation has greatest importance. The rate of uptake and partition of $\mathrm{N}$ is largely determined by supply and demand during various stages of plant growth (Amanullah et al., 2008). In most plants $\mathrm{N}$ is accumulated in the vegetative organs in the form of proteins. During grain filling, the nitrogen accumulated in the vegetative organs is remobilised to the ear; 60 to $95 \%$ of grain $\mathrm{N}$ comes from the remobilisation of $\mathrm{N}$ stored in roots and shoots before anthesis. After flowering, both the size and the $\mathrm{N}$ content of the grain can be significantly reduced under $\mathrm{N}$ deficient conditions (Triboi and Triboi-Blondel, 2002).

Nitrogen may strongly affect both crop yield and quality and, as such, has been studied to the greatest extent mainly for covered barley (Baethgen et al., 1995; Walter et al., 1995; Jankovic et al., 2011). Particularly for malting barley, adequate nitrogen management is essential, because high nitrogen availability is required for high yields, but if in excess it could be detrimental to quality (Marconi et al., 2011). Only a few experiments have examined the influence of agronomic factors on HB (Jackson et al., 1994; Thomason et al., 2012). Although HB is higher in energy density and protein than hulled barley, management recommendations for this new crop are lacking. The effect of different rates of $\mathrm{N}$ fertilizer application in Latvian conditions on hulless barley yield and grain quality is unknown. The objective of this study was to determine the effect of different levels of $\mathrm{N}$ on yield and grain quality for three hulless spring barley genotypes, in relation to weather characteristics. Based on previous studies, these selected genotypes showed the best results according to grain chemical traits that enhance the dietary value of grain (Bleidere et al., 2013).

\section{MATERIALS AND METHODS}

The field experiment. The field experiments were carried out at the State Stende Cereal Breeding Institute during two years (2011 and 2012) that differed in meteorological con- ditions. The experimental treatment consisted of nine factorial combinations of three hulless barley genotypes 'Kornelija'; 'ST 1165'; ST 1185' from the Stende spring barley breeding programme and three nitrogen $(\mathrm{N})$ rates N80 (N1); N120 (N2); N160 (N3). Complex mineral fertiliser NPK 16:16:16 was used as a basic fertiliser at rate 500 $\mathrm{kg} \mathrm{ha}^{-1}$ (pure matter $\mathrm{N}-80 \mathrm{~kg} \mathrm{ha}^{-1}, \mathrm{P}-35 \mathrm{~kg} \mathrm{ha}^{-1}, \mathrm{~K}-66$ $\mathrm{kg} \mathrm{ha}^{-1}$ ) in the field trial. The $\mathrm{N}$ application (N2 and N3) was split, part of the $\mathrm{N}$ being applied at the time of sowing and the remaining part at the end of the tillering stage (growing stage/GS 29) of the crop. Ammonium nitrate (N $34 \%$ ) was used as a top-fertiliser in the following amount: $40 \mathrm{~kg} \mathrm{~N} \mathrm{ha}^{-1}$ (N2) and $80 \mathrm{~kg} \mathrm{~N} \mathrm{ha}^{-1}$ (N3). The treatments were laid out in a randomised complete block design; the plot size was $10 \mathrm{~m} 2$, four replicates.

The barley was sown with a compact trial drill 'Hege 80' in a well prepared seedbed at a rate of 500 germinating seeds per $\mathrm{m}^{2}$. The yield was harvested by a combine 'Hege 140'.

Soil and weather characteristics. The soil under conventional growing conditions in both years was sod-podzolic sandy loam, content of organic substance $21-23 \mathrm{~g} \mathrm{~kg}^{-1}$, the soil pH KCL 5.4-5.9, the content of available for plants phosphorus $\mathrm{P}_{2} \mathrm{O}_{5}$ 137-145 $\mathrm{mg} \mathrm{kg}^{-1}$, and potassium $\mathrm{K}_{2} \mathrm{O}$ 198-211 $\mathrm{mg} \mathrm{kg}^{-1}$.

Overall, the growing seasons of 2011 was characterised by average temperature being above the long-term average observations (norm) data and some extreme periods of drought (Table 1). In 2011, hot and dry conditions occurred during the third decade of May and in the first decade of June. The average temperature was above to long-term average in June $\left(2.6{ }^{\circ} \mathrm{C}\right)$ and July $\left(2.9^{\circ} \mathrm{C}\right)$ (Table 1$)$. The growing season of 2012 was characterised by optimal temperature and moisture conditions, and by a lower number of sunny days. Moisture and temperature conditions during early stages of plant development were optimal. The average temperature in June was $1.0^{\circ} \mathrm{C}$ lower than the norm $\left(14.2^{\circ} \mathrm{C}\right)$. Many rainy and cloudy days during May and June contributed to slow barley growth and development. Also in July and August precipitation was more than usual.

Sampling, chemical and statistical analysis. The grain yield was measured for the whole plot. Samples for grain quality were taken from each plot. The following grain physical traits were evaluated: 1000 kernel weight/TKW (g) by ISTA method, and test weight/TW $\left(\mathrm{g} \mathrm{L}^{-1}\right)$ by automatic

Table 1

AVERAGE MONTHLY TEMPERATURE AND PRECIPITATION SUM IN STENDE, 2011-2012

\begin{tabular}{l|ccc|ccc}
\hline \multirow{2}{*}{ Month } & \multicolumn{3}{|c|}{ Average temperature, ${ }^{\circ} \mathrm{C}$} & \multicolumn{3}{c}{ Sum of precipitation, mm } \\
\cline { 2 - 7 } & 2011 & 2012 & norm & 2011 & 2012 & norm \\
\hline April & 6.9 & 5.6 & 4.3 & 26.8 & 42.7 & 37.0 \\
May & 10.6 & 11.0 & 10.2 & 54.7 & 58.9 & 45.0 \\
June & 16.8 & 13.2 & 14.2 & 59.6 & 78.7 & 57.0 \\
July & 19.2 & 17.5 & 16.3 & 165.3 & 91.7 & 87.0 \\
August & 16.3 & 15.5 & 15.5 & 155.0 & 115.1 & 87.0
\end{tabular}


grain analyser Infratec Analysis 1241. Macronutrient crude protein content/CP $\left(\mathrm{g} \mathrm{kg}^{-1}\right)$, starch content/ST $\left(\mathrm{g} \mathrm{kg}^{-1}\right)$, $\beta$-glucans content/BGL $\left(\mathrm{g} \mathrm{kg}^{-1}\right)$ were determined by an automatic grain analyzer Infratec Analysis 1241.

Mean samples from all replications were taken and milled for assessment of grain micronutrients. The total phenolic content (TPC) and 2.2-diphenyl-1-picrylhydrazyl (DPPH) antiradical scavenging activity (RSA) assay were determined according to the method described in literature (Ragaee et al., 2006) with some modifications. For the determination of TPC and for RSA 1.5 gram samples of grain flour were placed into Erlenmeyer flasks $(250 \mathrm{ml})$ and mixed with $30 \mathrm{ml}$ of $50 \%$ (vol.) ethanol. The mixture was stirred at $40{ }^{\circ} \mathrm{C}$ for $15 \mathrm{~min}$ and then at room temperature for $1 \mathrm{~h}$. After extraction the supernatant was filtered through a filter paper. The filtrate was used for the analysis of TPC and RSA.

The TPC determination method is based on the reduction of the Folin-Ciocalteu reagent by phenols to a mixture of reaction products, having absorbance maximum at $765 \mathrm{~nm} .1 \mathrm{ml}$ of extract was mixed with $5 \mathrm{ml}$ of $10 \%$ Folin-Ciocalteu's reagent in distilled water and $4 \mathrm{ml} \mathrm{7.5 \%} \mathrm{Na}_{2} \mathrm{CO}_{3}$ solution, stirred for $30 \mathrm{~min}$ at room temperature and the absorbance at $765 \mathrm{~nm}$ was measured using a spectrophotometer UVIKON 930 (Kontron Instruments, Italy). TPC was calculated using gallic acid as a standard and expressed as mg gallic acid equivalents per $100 \mathrm{~g}$ of grain dry weight (DW).

In RSA assay $0.4 \mathrm{ml}$ of extract (sample) or $50 \%$ (vol.) ethanol (control sample) was added to $3.6 \mathrm{ml}$ of $10^{-4} \mathrm{M} \mathrm{DPPH}$ solution in ethanol and mixed. The mixture was vigorously shaken and left to stand for $20 \mathrm{~min}$. The absorbance at 517 $\mathrm{nm}$ was measured against $50 \%$ (vol.) ethanol as a blank. The DPPH radical scavenging activity (\%) was calculated using equation (1):

$\operatorname{RSA}(\%)=\frac{\left(A_{\text {control })}-A_{\text {sample }}\right)}{A_{\text {control }}} \cdot 100 \%$, where

$A_{\text {control }}$ is the absorbance of the control sample; $A_{\text {sample }}$ is the absorbance of the sample.

Determination of $\alpha$-tocopherol $(\alpha-\mathrm{T})$ was done in the Laboratory of Food and Environmental Investigations Institute of Food Safety, Animal Health and Environment "BIOR" using the high-performance liquid-chromatography method for detection of $\alpha$-tocopherol in diet samples (Commission Directive 2000/45/EC). Chromatographical distribution was carried out on a $\mathrm{C}_{18}$ column using methanol/water $(98 / 2$ $\mathrm{v} / \mathrm{v})$. Fluorometric detection of all peaks was performed at an excitation wavelength of $292 \mathrm{~nm}$.

ANOVA procedures were used for statistical data analysis. In the analysis of variance, the partitioning of sum of squares $\left(\eta^{2}\right)$ due to the relative impact of each single factor was estimated. As three-way ANOVA indicated effect of year as highly significant $(P<0.01)$ and explained most of the variation of all investigated traits $\left(\eta^{2}=21-80 \%\right)$, two-way ANOVA was conducted separately for each year. One-way analysis of variance was used to determine $95 \%$ confidence intervals for the difference between HB genotypes within each $\mathrm{N}$ rate. A t-test (paired two samples for means) was used to test for differences among the grand means of the two years. The significance of effect of factors was determined at probability level of 0.05 .

\section{RESULTS}

Yield. ANOVA showed that there were differences between years in effects on grain yield. In 2011, the variation of grain yield of HB in the tested genotypes was mainly determined by interaction of factors $\left(\eta^{2}=45 \%\right)$ and genotype $\left(\eta^{2}=37 \%\right)$ (Table 2$)$. In this year there was no significant influence of $\mathrm{N}$ treatment on average yield. In 2012, the determinant of average yield variation was mainly genotype $\left(\eta^{2}=54 \%\right)$. Also, the rate of $\mathrm{N}$ fertiliser addition was an influential agronomic variable affecting yield of HB in 2012 $\left(\eta^{2}=7 \%\right)$.

Between the years of investigation there were differences between $\mathrm{HB}$ varieties in grain yield at different $\mathrm{N}$ rates. In 2011 , by increasing nitrogen from 80 to $120 \mathrm{~kg} \mathrm{ha}^{-1}$, the grain yield increased significantly (2.73 to $3.50 \mathrm{t} \mathrm{ha}^{-1}$ ) only for variety 'Kornelija' (Table 3). For the other two genotypes topdressing nitrogen (N120; N160) significantly decreased grain yield. Breeding line ' 1185 ' showed significantly higher mean grain yield $\left(3.51 \mathrm{t} \mathrm{ha}^{-1}\right)$. The grand mean for grain yield $\left(3.19 \mathrm{t} \mathrm{ha}^{-1}\right)$ in 2011 was significantly lower, compared with grain yield (5.31 t ha-1) in 2012 . Grain yield responded positively for all genotypes to increased $\mathrm{N}$ fertiliser top-dressing rate $\left(40 \mathrm{~kg} \mathrm{ha}^{-1}\right)$. Higher $\mathrm{N}$ top-dressing rate $\left(80 \mathrm{~kg} \mathrm{ha}^{-1}\right)$ did not influence significantly the grain yield. Overall, the maximum average yield was obtained with $\mathrm{N}$ application $120 \mathrm{~kg} \mathrm{ha}^{-1}$. Also in 2012, hulless barley line ' 1185 ' had a significantly higher mean grain yield $\left(6.00 \mathrm{t} \mathrm{ha}^{-1}\right)$.

Grain physical traits. Analysis of variance showed that there were differences between years in the effect of factors on 1000 kernel weight (TKW). In 2011, the variation of

Table 2

PARTITIONING OF SUM OF SQUARES $\left(\eta^{2}\right)$ OF MEASURED TRAITS FOR HULLESS BARLEY GENOTYPES UNDER DIFFERENT RATES OF N APPLICATION, 2011-2012

\begin{tabular}{l|c|c|c|c|c|c}
\hline & Yield & TKW & TW & CP & ST & BGL \\
\hline 2011 & & & & & & \\
N treatment (A) & 2 & 2 & $46^{*}$ & $14^{*}$ & $10^{*}$ & $4^{*}$ \\
Genotype (B) & $37^{*}$ & $64^{*}$ & 1 & $79 *$ & $81^{*}$ & $72^{*}$ \\
A x B & $45^{*}$ & 1 & 3 & $2 *$ & 2 & 3 \\
2012 & & & & & & \\
N treatment (A) & $7 *$ & $28^{*}$ & $15^{*}$ & $58^{*}$ & $74^{*}$ & $28^{*}$ \\
Genotype (B) & $54^{*}$ & $27^{*}$ & $32^{*}$ & $1^{*}$ & 2 & $29 *$ \\
A x B & 4 & $25^{*}$ & $24^{*}$ & $36^{*}$ & 5 & 5
\end{tabular}

*Significant at 5\%; TKW, 1000 kernel weight; TW, test weight; CP, crude protein; ST, starch; BGL, $\beta$-glucans. 
Table 3

GRAIN YIELD (T HA ${ }^{-1}$ ) OF HULLESS BARLEY GENOTYPES UNDER DIFFERENT RATES OF N APPLICATION, 2011-2012

\begin{tabular}{l|c|c|c|c|c|c|c|c}
\hline \multirow{2}{*}{ Genotype } & \multicolumn{5}{|c|}{2011} & \multicolumn{4}{c}{2012} \\
\cline { 2 - 10 } & N80 & N120 & N160 & mean & N80 & N120 & N160 & mean \\
\hline Kornelija & 2.73 & 3.50 & 3.72 & 3.32 & 4.62 & 5.21 & 5.03 & 4.95 \\
1165 & 3.31 & 2.41 & 2.52 & 2.75 & 4.69 & 5.24 & 5.00 & 4.98 \\
1185 & 3.85 & 3.44 & 3.24 & 3.51 & 6.07 & 6.19 & 5.74 & 6.00 \\
Mean & 3.30 & 3.11 & 3.16 & $3.19 b^{2}$ & 5.13 & 5.55 & 5.26 & $5.31 \mathrm{a}$ \\
LSD $_{0.05}^{1}$ & 0.522 & 0.508 & 0.609 & - & 0.796 & 0.806 & 0.618 & - \\
LSD $_{0.05 \text { factor }}$ & 0.201 & & & & 0.344 & & & \\
\hline
\end{tabular}

${ }^{1} 95 \%$ confidence intervals for the difference between genotypes within each $\mathrm{N}$ rate; ${ }^{2}$ Estimates of grand means with different letters between years are significant $(P<0.05)$.

TKW in the tested HB genotypes was significantly determined only by genotype $\left(\eta^{2}=64 \%\right)$ but in 2012 all factors affected this trait significantly and to a similar extent $\left(\eta^{2}=\right.$ 25-28\%) (Table 2). In both years of the investigation the highest TKW in all $\mathrm{N}$ fertiliser treatments was by variety 'Kornelija' (mean value $47.7 \mathrm{~g}$ and $51.5 \mathrm{~g}$, respectively) (Table 4). In 2012, TGW was significantly higher with application of top-dressing $\mathrm{N}$ rate $\left(40 \mathrm{~kg} \mathrm{~N} \mathrm{ha}^{-1}\right)$ at GS 29 (mean value $51.6 \mathrm{~g})$. A higher top-dressing $\mathrm{N}$ rate $(80 \mathrm{~kg} \mathrm{~N}$ $\mathrm{ha}^{-1}$ at GS 29) influenced negatively the size of HB grains.

In 2011, the variation of HB test weight (TW) was significantly determined only by $\mathrm{N}$ fertiliser rates. The highest TW was obtained by applying $80 \mathrm{~kg} \mathrm{~N} \mathrm{ha}^{-1}$ at sowing. Increasing the nitrogen amount during the tillering growth stage decreased TW significantly for all hulless genotypes. Apart from nitrogen rate, the genotype and interaction of both factors also affected significantly the variation of TW

Table 4

GRAIN PHYSICAL TRAITS OF HULLESS BARLEY GENOTYPES UNDER DIFFERENT RATES OF N APPLICATION, 2011-2012

\begin{tabular}{|c|c|c|c|c|c|c|c|c|}
\hline \multirow[t]{2}{*}{ Genotype } & \multicolumn{4}{|c|}{2011} & \multicolumn{4}{|c|}{2012} \\
\hline & N80 & $\mathrm{N} 120$ & $\mathrm{~N} 160$ & mean & N80 & N120 & N160 & mean \\
\hline \multicolumn{9}{|c|}{1000 kernel weight, g } \\
\hline Kornelija & 48.2 & 47.6 & 47.5 & 47.7 & 49.0 & 52.3 & 53.1 & 51.5 \\
\hline 1165 & 44.3 & 43.8 & 43.6 & 43.9 & 45.0 & 50.9 & 49.5 & 48.4 \\
\hline 1185 & 44.9 & 45.4 & 44.4 & 43.7 & 45.7 & 51.8 & 42.1 & 46.5 \\
\hline Mean & 45.8 & 45.6 & 45.2 & $45.5 b^{* 2}$ & 46.6 & 51.6 & 48.2 & $48.8 \mathrm{a}$ \\
\hline $\mathrm{LSD}_{0.05}{ }^{1}$ & 2.355 & 1.585 & 2.093 & - & 3.237 & 2.931 & 2.140 & - \\
\hline $\mathrm{LSD}_{0.05 \text { factors }}$ & 0.985 & & & & 1.544 & & & \\
\hline \multicolumn{9}{|c|}{ Test weight, $\mathrm{g} \mathrm{L}^{-1}$} \\
\hline Kornelija & 745.5 & 734.2 & 729.7 & 736.5 & 807.7 & 801.7 & 800.7 & 803.4 \\
\hline 1165 & 746.2 & 731.7 & 727.5 & 735.2 & 799.2 & 788.7 & 780.2 & 789.4 \\
\hline 1185 & 740.0 & 732.7 & 732.7 & 734.4 & 787.0 & 795.2 & 755.2 & 779.1 \\
\hline Mean & 743.9 & 732.9 & 729.2 & $735.4 b$ & 798.0 & 792.6 & 781.4 & $790.7 \mathrm{a}$ \\
\hline $\mathrm{LSD}_{0.05}$ & 13.69 & 8.70 & 14.00 & - & 8.58 & 13.65 & 19.95 & - \\
\hline $\mathrm{LSD}_{0.05 \text { factors }}$ & 6.215 & & & & 8.698 & & & \\
\hline
\end{tabular}

\footnotetext{
${ }^{1} 95 \%$ confidence intervals for the difference between genotypes within each $\mathrm{N}$ rate; ${ }^{2}$ Estimates of grand means with different letters between years are significant $(P<0.05)$.
}

in 2012. Also in this year, the highest (significantly) TW was obtained by applying the nitrogen only at sowing time $\left(80 \mathrm{~kg} \mathrm{ha}^{-1}\right)$. Variety 'Kornelija' had significantly higher TW (803.4 $\mathrm{g} \mathrm{L}^{-1}$ ) than for other two genotypes. Overall, both of the physical traits (TKW and TW) were significantly higher in 2012.

Grain chemical traits. According to analysis of variance in 2011, the variation of traits of HB grain chemical composition was mainly determined by genotype $\left(\eta^{2}=72-81 \%\right)$ (Table 2). Also $\mathrm{N}$ fertiliser as a factor affected significantly chemical composition, and in 2012 more than in $2011\left(\eta^{2}=\right.$ $28-74 \%)$. Grain protein responded positively to increasing rates, as additional $\mathrm{N}$ at GS $29\left(80 \mathrm{~kg} \mathrm{~N} \mathrm{ha}^{-1}\right)$ increased the mean value of crude protein by $16.3 \mathrm{~g} \mathrm{~kg}^{-1}$ in 2011 and by $22.9 \mathrm{~g} \mathrm{~kg}^{-1}$ in 2012, compared with that achieved with only $\mathrm{N}$ application at sowing time (Table 4). The grand mean of crude protein was significantly higher in 2011 than in 2012 (169.4 and $129.2 \mathrm{~g} \mathrm{~kg}^{-1}$, respectively). Variety 'Kornelija' had the highest crude protein in both years of the investigation.

The grand mean of starch content was significantly higher in 2012 than in 2011 (624.0 and $603.0 \mathrm{~g} \mathrm{~kg}^{-1}$, respectively). Nitrogen rate influenced differently the variation of $\mathrm{HB}$ starch content in both years of investigation. In 2011, to reach the maximum starch content in grain $\left(606.9 \mathrm{~g} \mathrm{~kg}^{-1}\right)$, $80 \mathrm{~kg} \mathrm{~N} \mathrm{ha}^{-1}$ was sufficient, but in 2012 the maximum starch content $\left(630.1 \mathrm{~g} \mathrm{~kg}^{-1}\right)$ was obtained by applying additionally $80 \mathrm{~kg} \mathrm{~N} \mathrm{ha}^{-1}$ (Table 4). A significant difference $(P<0.05)$ between genotypes in starch content was found only in 2011 , when HB line ' 1185 ' had grain with significantly higher starch content than other both genotypes.

The grand mean of $\beta$-glucans content was significantly higher in 2012 than in 2011 (53.0 and $47.1 \mathrm{~g} \mathrm{~kg}^{-1}$ respectively). In both years of investigation the maximum $\beta$-glucans content was obtained at the highest $\mathrm{N}$ fertilizer rate $\left(160 \mathrm{~kg} \mathrm{~N} \mathrm{ha}^{-1}\right)$. A significant difference was observed between $\mathrm{HB}$ genotypes in $\beta$-glucans content. The highest $\beta$-glucans content in grain was observed for the variety 'Kornelija' in both years of investigation (53.5-56.3 $\mathrm{g} \mathrm{kg}^{-1}$ ) (Table 5).

In 2011 , to reach the maximum $\alpha$-tocopherol in grain (8.7 $\left.\mathrm{mg} \mathrm{kg}^{-1}\right), 80 \mathrm{~kg} \mathrm{~N} \mathrm{ha}^{-1}$ was sufficient, but in 2012 the maximum $\alpha$-tocopherol content $\left(10.6 \mathrm{mg} \mathrm{kg}^{-1}\right)$ was obtained by applying additionally $80 \mathrm{~kg} \mathrm{~N} \mathrm{ha}^{-1}$ at GS 29 (Table 6). The highest content of $\alpha$-tocopherol in grain was observed for the hulless line ' 1185 '. Nitrogen rate influenced differently the variation of antiradical scavenging activity (RSA) for HB in the years of study (Table 6). In 2011, higher RSA was observed by application of $\mathrm{N}$ at rate $120 \mathrm{~kg} \mathrm{~N} \mathrm{ha}^{-1}$. In 2012 , the maximum value of the trait was reached already with $\mathrm{N}$ rate $80 \mathrm{~kg} \mathrm{~N} \mathrm{ha}^{-1}$. Hulless barley genotype ' 1185 ' showed the highest RSA in both years of investigation. Positive response to additional $\mathrm{N}$ at later growth stages was found for total phenolic content in grains. In the years it was increased by $14 \%$ and $10 \%$, respectively. The best re- 
GRAIN CHEMICAL TRAITS OF HULLESS BARLEY GENOTYPES UNDER DIFFERENT RATES OF N APPLICATION, 2011-2012

\begin{tabular}{|c|c|c|c|c|c|c|c|c|}
\hline \multirow[t]{2}{*}{ Genotype } & \multicolumn{4}{|c|}{2011} & \multicolumn{4}{|c|}{2012} \\
\hline & $\mathrm{N} 80$ & $\mathrm{~N} 120$ & N160 & mean & N80 & $\mathrm{N} 120$ & N160 & mean \\
\hline \multicolumn{9}{|c|}{ Crude protein, $\mathrm{g} \mathrm{kg}^{-1}$} \\
\hline Kornelija & 188.8 & 189.8 & 196.8 & 191.7 & 112.0 & 148.3 & 159.5 & 130.5 \\
\hline 1165 & 151.8 & 159.3 & 169.8 & 160.2 & 133.8 & 121.8 & 134.5 & 130.0 \\
\hline 1185 & 145.3 & 155.3 & 168.0 & 156.2 & 117.5 & 125.5 & 138.0 & 127.0 \\
\hline Mean & 161.9 & 168.1 & 178.2 & $169.4 a^{1}$ & 121.1 & 122.4 & 144.0 & $129.2 b$ \\
\hline $\mathrm{LSD}_{0.05}{ }^{2}$ & 4.55 & 6.87 & 8.98 & - & 5.04 & 2.83 & 5.48 & - \\
\hline $\mathrm{LSD}_{0.05 \text { factors }}$ & 3.797 & & & & 2.795 & & & \\
\hline \multicolumn{9}{|c|}{ Starch, $\mathrm{g} \mathrm{kg}^{-1}$} \\
\hline Kornelija & 591.0 & 589.3 & 588.3 & 589.5 & 615.0 & 623.0 & 629.3 & 622.4 \\
\hline 1165 & 611.8 & 607.0 & 600.8 & 606.5 & 623.0 & 627.0 & 632.3 & 624.8 \\
\hline 1185 & 618.0 & 613.8 & 606.8 & 612.8 & 629.3 & 632.3 & 628.7 & 624.4 \\
\hline Mean & 606.9 & 603.3 & 598.5 & $603.0 \mathrm{~b}$ & 614.8 & 626.8 & 630.1 & $624.0 \mathrm{a}$ \\
\hline $\mathrm{LSD}_{0.05}$ & 4.63 & 3.50 & 7.10 & - & 5.41 & 2.37 & 3.70 & - \\
\hline $\mathrm{LSD}_{0.05 \text { factors }}$ & 2.823 & & & & 2.701 & & & \\
\hline \multicolumn{9}{|c|}{$\beta$-glucan, $\mathrm{g} \mathrm{kg}^{-1}$} \\
\hline Kornelija & 53.5 & 53.8 & 53.3 & 53.5 & 55.3 & 55.5 & 58.0 & 56.3 \\
\hline 1165 & 44.5 & 44.5 & 47.0 & 45.3 & 50.0 & 53.5 & 59.0 & 54.2 \\
\hline 1185 & 39.8 & 42.0 & 45.3 & 42.3 & 47.0 & 49.0 & 53.8 & 49.9 \\
\hline Mean & 45.9 & 46.8 & 48.5 & $47.1 \mathrm{~b}$ & 50.8 & 52.7 & 56.9 & $53.0 \mathrm{a}$ \\
\hline $\mathrm{LSD}_{0.05}$ & 3.12 & 6.32 & 3.94 & - & 4.39 & 5.51 & 5.90 & - \\
\hline $\mathrm{LSD}_{0.05 \text { factors }}$ & 2.065 & & & & 2.843 & & & \\
\hline
\end{tabular}

${ }^{1} 95 \%$ confidence intervals for the difference between genotypes within each $\mathrm{N}$ rate; ${ }^{2}$ Estimates of grand means with different letters between years are significant $(P<0.05)$.

Table 6 MICRONUTRIENT CONTENT OF HULLESS SPRING BARLEY LINES UNDER DIFFERENTRATES, OF N APPLICATION, AVERAGE OF 2011-2012

\begin{tabular}{|c|c|c|c|c|c|c|c|c|}
\hline \multirow[t]{2}{*}{ Genotype } & \multicolumn{4}{|c|}{2011} & \multicolumn{4}{|c|}{2012} \\
\hline & N80 & N120 & N160 & mean & N80 & N120 & N160 & mean \\
\hline \multicolumn{9}{|c|}{$\alpha$-tocopherol, $\mathrm{mg} \mathrm{kg}^{-1}$} \\
\hline Kornelija & 9.3 & 9.1 & 7.8 & 8.7 & 11.7 & 9.6 & 9.3 & 10.2 \\
\hline 1165 & 7.2 & 8.1 & 7.3 & 7.5 & 7.1 & 10.5 & 10.5 & 9.4 \\
\hline 1185 & 9.6 & 8.0 & 9.1 & 8.9 & 9.2 & 10.9 & 11.9 & 10.7 \\
\hline Mean & 8.7 & 8.4 & 8.1 & $8.4 \mathrm{~b}$ & 9.3 & 10.3 & 10.6 & $10.1 \mathrm{a}$ \\
\hline \multicolumn{9}{|c|}{ Antiradical scavenging activity, $\%$} \\
\hline Kornelija & 46.0 & 46.7 & 50.2 & 47.6 & 41.7 & 44.5 & 43.0 & 43.1 \\
\hline 1165 & 41.3 & 47.3 & 51.8 & 46.8 & 42.0 & 40.7 & 42.8 & 41.8 \\
\hline 1185 & 52.0 & 56.9 & 49.8 & 52.9 & 59.0 & 55.1 & 49.6 & 54.6 \\
\hline Mean & 46.4 & 50.3 & 50.6 & $49.1 \mathrm{a}$ & 47.6 & 46.8 & 45.1 & $46.5 \mathrm{~b}$ \\
\hline \multicolumn{9}{|c|}{ Total phenolic content, mg GAE $100 \mathrm{~g}^{-1} \mathrm{DM}$} \\
\hline Kornelija & 183.6 & 186.8 & 207.6 & 192.7 & 165.9 & 175.1 & 174.9 & 171.9 \\
\hline 1165 & 169.7 & 214.7 & 226.9 & 203.8 & 184.3 & 205.1 & 219.8 & 203.0 \\
\hline 1185 & 179.1 & 188.4 & 172.3 & 179.9 & 187.4 & 210.2 & 194.7 & 197.4 \\
\hline Mean & 177.5 & 196.6 & 202.3 & $192.1 \mathrm{a}$ & 179.2 & 196.8 & 196.5 & $190.8 \mathrm{a}$ \\
\hline
\end{tabular}

*Estimates of grand means with different letters between years are significant $(P<0.05)$. sults for this trait were consistently shown by the hulless line ' 1165 '.

\section{DISCUSSION}

Grain yield and quality traits of spring barley can vary greatly due to growing conditions (Leistrumaite and Paplauskiene, 2005). In a previous study, also at Stende, a significant effect of year on variation of yield of HB genotypes was also observed (Bleidere et al., 2012). Overall in this current study, grain yield, TGW, TW, starch and $\beta$-glucans in 2011 were significantly lower than in 2012. Large differences in meteorological conditions occurred between the trial years in the period until flowering, which is the most important period for barley plants growth and intensive uptake of nutrients from soil. In 2011, hot and dry conditions occurred during the third decade of May and in the first decade of June, while in 2012 the moisture conditions during this period were optimal. This might be the main reason why in 2011 there was no significant positive effect from additional split $\mathrm{N}$ application on yield, TKW, TW and starch content, as $\mathrm{N}$ availability was governed by rainfall patterns. Also H. Mouchova et al., (1996) found that the efficiency of applied nitrogen fertilizers and their loss are influenced by the interaction of many factors, such as 
type of soil, crop, agricultural practice, including the dose, the form, the time of fertilisation and also the weather of the year. Soil N supply, for example must be high at tillering, stem elongation, booting, heading and grain filling, as it is required fo development and growth of reproductive organs and for an enhanced and high accumulation of nutrition quality attributes in the kernel (Amanullah et al., 2008).

Nitrogen application has been shown to significantly increase TKW and TW in covered barley (Walter et al., 1995; Jankovic et al., 2011). Grain yield of hulless barley responded positively to increasing $\mathrm{N}$ rates, as additional $\mathrm{N}$ at tillering stage was related to increased grain TW (Thomason et al., 2012). In the wet year of 2012 all HB showed significant response to additional application of $\mathrm{N}$ at the end of tillering stage, when the highest grain yield and TKW (at N120), and crude protein, starch and $\beta$-glucans (at N160) were recorded. Split application of nitrogen significantly increased the content of crude protein and $\beta$-glucans also in a study by O. Marconi et al. (2011). Nitrogen fertilizer application, while often required to increase grain yield, may also reduce physical grain quality traits. Declines in TW, TKW and percent plump kernels, and increases in percent thin kernels have resulted from increasing $\mathrm{N}$ rates (Jackson et al. 1994). In the current study in both years of investigation grain TW of HB was not affected by additional application of $\mathrm{N}$.

Hulless barley genotypes included in this study showed results that were similar to those reported earlier (Ehrenbergerova et al. 2006) in the Czech Republic. In the favourable 2012 of current study, the maximum $\alpha$-tocopherol content was obtained using the highest $\mathrm{N}$ fertilizer rate (160 $\mathrm{kg} \mathrm{N} \mathrm{ha}^{-1}$ ). This means $\alpha$-tocopherol content is affected by nitrogen management conditions. Also Cavarello et al., (2004) indicated that both genotype and environment influenced the total tocol content in HB. Fertilization application significantly increased the content of isomer $\alpha$-tocopherol (by $0.9 \mathrm{mg} \mathrm{kg}^{-1}$ ) in the research of Ehrenbergerova et al. (2006). There was a significant decrease of $\alpha$-tocopherol in varieties grown under organic cultivation conditions, where limited availability of nitrogen is characteristic (Tsochatzis et al., 2012).

The present research indicates that $\mathrm{HB}$ could be a good source of total phenolic compounds, as reported previously (Zhao et al. 2008). In a study of HB genotypes of Latvian origin (Dabina-Bicka et al. 2011) similar results for TPC were obtained as in our study. We found no scientific reports on fluctuation of micronutrients, such as total phenolic content, and antiradical activity, under different $\mathrm{N}$ management conditions in barley. According to results obtained in the current research it is possible to increase TPC by additional nitrogen application.

As the variation of grain yield and almost grain quality traits in the tested genotypes was significantly determined by genotype and their interaction with $\mathrm{N}$, the HB genotypes performed differently depending on $\mathrm{N}$ management conditions. In both years, line ' 1185 ' characterized had the best results according to grain yield and starch content. Variety 'Kornelija' showed significantly higher TKW, crude protein and $\beta$-glucans content than for the other two genotypes. Test weights for 'Kornelija' were also higher than for other varieties in the favourable year 2012. Thus, these two genotypes differ in ability to use nitrogen inputs for yield and grain quality formation. In a previous study (Qi et al. 2006), grain protein content was significantly affected by both $\mathrm{N}$ treatment and genotype, but there was no significant interaction between $\mathrm{N}$ treatment and genotype.

Overall the study showed that the effects of genotype, $\mathrm{N}$ treatment and genotype by $\mathrm{N}$ treatment interaction significantly contribute to variation in yield and grain quality traits for hulless barley genotypes. The moisture regime during the tillering stage of a particular year can influence the effectiveness of $\mathrm{N}$ fertilizer in increasing yield and grain nutritional quality. In addition to nitrogen fertilisation, variety selection was also found to have a significant influence on yield and grain quality in HB. Our results indicate that manipulation of nitrogen fertilisation levels can improve grain biochemical composition, which can be recommended for dietary products. It is particularly important to increase the amounts of macro and micronutrients in the HB grain harvest.

\section{ACKNOWLEDGEMENTS}

This study is performed with financial support of European Regional Development Fund co-financed project No. 2DP/2.1.1.1.0/10/APIA/VIAA/083.

\section{REFERENCES}

Amanullah, R. A., Khalil, S. K. (2008). Effects of plant density and N on phenology and yield of cereals. J. Plant Nutr., 32, 246-260.

Ames, N., C. Rhymer, B. Rossnagel, M. Therrien, D. Ryland, S. Dua, K. Ross. (2006). Utilization of diverse hulless barley properties to maximize food product quality. Cereal Foods World, 51 (1), 23-28.

Ames, N. P., Rhymer C. R. (2008). Issues surrounding health claims for barley. J. Nutr., 138, 1237-1243.

Baethgen, W. E., Christiansom, C. B., Lamothe, A. G. (1995). Nitrogen fertilizer effects on growth, grain yield, and yield components of malting barley. Field Crop Res., 43, 87-99.

Bleidere, M., Mežaka, I., Legzdina, L., Grunte, I., Beinarovica, I.,Rostoks, N. (2012). Variation of spring barley agronomic traits significant for adaption to climate change in Latvian breeding programmes. Proc. Latvian Acad. Sci., Section B, 66 (1/2), 30-35.

Bleidere, M., Zute, S., Jakobsone, I. (2013). Characterisation of physical and biochemical traits of hulless spring barley grain in Latvian breeding program. Proc. Latvian Acad. Sci., Section B (in press).

Cavarelo, A., Gianineti, A., Finocchiaro, D. A., Stanca, A. M. (2004). Tocols in hull-less and hulled barley genotypes grown in contrasting environments. J. Cereal Sci., 39, 175-180.

Charalampopouos, D., Wang, R., Pandiella, S. S., Webb, C. (2002). Application of cereals and cereal components in functional foods: A review. Int. J. Food Microbiol., 79 (1-2), 131-41.

Colombo, M. L. (2010). An update on vitamin E, tocopherol and tocotrienol-perspectives. Molecules, 15, 2103-2113.

Dabina-Bicka, I., Karklina, D., Kruma, Z. (2011). Polyphenols and vitamin E as potential antioxidants in barley and malt. Proceedings of 6th Baltic Con- 
ference on Food Science and Technology: Innovations for Food Science and Production, FOODBALT-2011, 5-6 May, 2011, Jelgava, pp. 121-126.

Dykes, L., Rooney, L. W. (2007). Phenolic compounds in cereal grains and their health benefits. Cereal Food World, 52, 105-111.

Ehrenbergerova J., Belcrediova, N., Pryma J. K., Newman C. W. (2006). Effect of cultivar, year grown, and cropping system on the content of tocopherols and tocotrienols in grains of hulled and hulless barley. Plant Foods Human Nutr., 61 (3), 145-150.

Guler, M. (2003). Barley grain $\beta$-glucan content as affected by nitrogen and irrigation. Field Crops Res., 84, 335-340.

Halliwell, B. (2007). Dietary polyphenols: Good, bad, or indifferent for our health? Cardiovasc. Res., 73, 341-347.

Jackson, G. D., Berg, R. K., Kushnak, G. D., Blake, T. K., Yarrow, G. I. (1994). Nitrogen effects on yield, beta-glucan content, and other quality factors of oat and waxy hulless barley. Commun. Soil Sci.Plant Anal., 25, 3047-3055.

Jankovic, S., Glamoclija, D., Maletic, R., Rakic, S., Hristov, N., Ikanovic J. (2011). Effect of nitrogen on yield and grain quality in malting barley. Afr. J. Biotechnol., 10 (84), 534-541

Leistrumaite, A., Paplauskiene, V. (2005). Genetic resources of spring barley: Screening for yield stability and grain malt quality traits. Biologija, $\mathbf{3}$, 23-26.

Marconi, O., Sileoni, V., Sensidoni, M., Rubio, J. M., Perretti, G., Fantozzi, P. (2011). Influence of barley variety, timing of nitrogen fertilisation and sun pest infestation on malting and brewing. J. Sci. Food Agricult., 91 (5), $820-830$.

Mouchova, H., Klir, J., Lippold, H. (1996). Effect of weather conditions and time of $\mathrm{N}$ application on the uptake of soil and applied $\mathrm{N}$ by winter wheat.
In.: Progress in Nitrogen Cycling Studies (pp. 237-241). Van Cleemput, O., Hofman, G., Vermoesen, A. (eds.). Kluwer Academic Publishers.

Newman, C. W., Newman, R. K. (2006). A brief history of barley foods. Cereal Foods World, 51, 4-7.

Pins, J. J., Kaur, H. (2006). A review of the effects of barley $\beta$-glucan on cardiovascular and diabetic risk. Cereal Foods World, 51, 8-12.

Qi, J. C., Zhang, G. P., Zhou, M. X. (2006). Protein and hordein content in barley seeds as affected by nitrogen level and their relationship to beta-amylase activity. J. Cereal Sci., 43, 102-107.

Ragaee, S., Abdel-Aal, E.-S. M., Noaman, M. (2006). Antioxidant activity and nutrient composition of selected cereals for food use. Food Chem., 98 (1), 32-38

Thomason, W. E., Phylips, S. B., Warren, J. A., Alley, M. M. (2012). Winter hulless barley response to nitrogen rate and timing and foliar phosphorus. $J$. Plant Nutr., 35 (2), 225-234

Triboi, E., Triboi-Blondel, A. M. (2002). Productivity and grain or seed composition: A new approach to an old problem. Invited paper. Eur. J. Agron., 16, 163-186.

Tsochatzis, E. D., Bladenopoulos, K., Papageorgiou, M. (2012). Determination of tocopherol and tocotrienol content of Greek barley varieties under conventional and organic cultivation techniques using validated reverse phase high-performance liquid chromatography method. J. Sci. Food Agricult., 92 (8), 1732-1739.

Walter, E. B., Christianson, C. B., Lamothe, A. G. (1995). The effect of nitrogen fertilizer on growth, grain yield and yield component of malting barley. Field Crop Res., 43, 87-99.

Zhao, H., Fan, W., Dong, J., Lu, J., Chen, J., Shan, L., Lin, Y., Kong, W. (2008). Evaluation of antioxidant activities and total phenolic contents of typical malting barley varieties. Food Chem., 107, 296-304.

Received 10 April 2013

\section{KAILGRAUDU MIEŽU RAŽAS UN GRAUDU KVALITĀTES IZPĒTE DAŽĀDOS AUDZĒŠANAS APSTĀKLOSOS AR ATŠKIRĪGU SLĀPEKL,A MĒSLOJUMA NODROŠINĀJUMU}

Pētījuma mērkis bija novērtēt graudu ražas un tās kvalitātes rādītāju (1000 graudu masas, tilpummasas, kopproteīna, cietes, $\beta$-glukānu, kopējo fenolsavienojumu, antiradikālās aktivitātes un $\alpha$-tokoferola satura) mainību trīs kailgraudu miežu (Hordeum vulgare L.) genotipiem, audzējot tos apstākḷos ar atškirīgu slāpekḷa nodrošinājumu un ievērojot meteoroloğisko apstākḷu īpatnības. Lauka izmēǵinājumi (2011.-2012. g.) iekārtoti Valsts Stendes graudaugu selekcijas institūtā konvencionālā lauka apstākḷıs ar trīs N mēslojuma variantiem (N80; N80+40; N80+80), slāpekḷa devu N80 dodot kopā ar pamatmēslojumu pirms sējas un papildmēslojumā — augu cerošanas beigās (29 etaps). Kailgraudu miežu ražas un graudu kvalitātes pazīmju mainību ietekmēja genotips, N mēslojuma norma un abu faktoru mijiedarbība. 2012. gadā, kad nokrišņu daudzums cerošanas un stiebrošanas fāzēs bija optimāls, iegūta būtiski $(P<0.05)$ augstāka graudu raža, 1000 graudu masa, tilpummasa, cietes un $\beta$-glikānu saturs graudos, salīdzinot ar 2011. gadu. 2012. gadā N mēslojuma ietekmē būtiski $(P<0.05)$ pieauga graudu raža, 1000 graudu masa, kopproteīna saturs (pie N120), cietes un $\beta$-glikānu saturs (pie N 160). Pie slāpekḷa mēslojuma normas 160 kg N ha ${ }^{-1}$ ieguva augstāko kopējo fenolu saturu, antiradikālo aktivitāti (2011. g.) un $\alpha$-tokoferola saturu graudos (2012. g.). Kailgraudu miežu līnija '1185' nodrošināja augstāko graudu ražu, cietes, $\alpha$-tokoferola saturu graudos un augstāko antiradikālo aktivitāti, bet šḳirnei 'Kornēlija' bija būtiski augstākā 1000 graudu masa, koproteīna un $\beta$-glikānu saturs graudos. 